\title{
Clinical study of pancreatitis and its management
}

\author{
Vipul V. Nandu*, Amol V. Deshpande \\ Department of Surgery, Shri V.N. Govt. Medical College, Yavatmal, Maharashtra, India
}

Received: 31 May 2016

Accepted: 02 July 2016

\author{
*Correspondence: \\ Dr. Vipul V Nandu, \\ E-mail: dr.vipulnandu@gmail.com
}

Copyright: (C) the author(s), publisher and licensee Medip Academy. This is an open-access article distributed under the terms of the Creative Commons Attribution Non-Commercial License, which permits unrestricted non-commercial use, distribution, and reproduction in any medium, provided the original work is properly cited.

\begin{abstract}
Background: Pancreatitis has been recognized since antiquity but the importance of pancreas and the severity of its inflammatory disorders were realized only in middle of $19^{\text {th }}$ century. Pancreatitis by itself is a disease which is unique, protean and extrudes into the diagnostic arena. Objectives of the study was to study the demographic characteristics of pancreatitis, and to study the various etiological factors of pancreatitis, and to study the clinical presentation of pancreatitis and its management.

Methods: Total 142 patients were enrolled over a period of 3 years for the study. Cases were studied with reference to clinical history and physical findings. Treatment was planned according to the severity of pancreatitis and presence or absence of complications with either conservative or surgical methods. Patients were followed up for 6 months to look for recurrence or complications developing after discharge.

Results: $92.25 \%$ patients were male. Highest incidence was noted in 20-40 years age group (mean- 38.94 years). More common among unskilled workers. Alcohol was the most common cause $(78.17 \%$ patients). Abdominal pain and epigastric tenderness being the most common mode of presentation. Most of the patients were managed conservatively. Duration of hospital stay for most of the patients was 4 to 9 days. Fluid collection in abdomen was the most common complication of pancreatitis.

Conclusions: Acute pancreatitis is a common cause of acute abdomen in patients presenting to the surgical emergency department. The management is mainly conservative with surgery limited to only a few selected cases, depending upon the severity of the disease.
\end{abstract}

Keywords: Pancreas, Pancreatitis

\section{INTRODUCTION}

The pancreas is a glandular organ in the digestive system and endocrine system of vertebrates. It is an endocrine gland producing several important hormones including insulin, glucagon, somatostatin and pancreatic polypeptide which circulate in the blood. The pancreas is also a digestive organ secreting pancreatic juice containing digestive enzymes that assist digestion and absorption of nutrients in the small intestine. These enzymes help further breakdown of carbohydrates, proteins and lipids in the chyme.
Pancreatitis has been recognized since antiquity but the importance of pancreas and the severity of its inflammatory disorders were realized only in middle of 19th century. ${ }^{1-3}$ Acute pancreatitis (AP) is a common condition involving the pancreas. The estimated incidence is about $3 \%$ of cases presenting with pain in abdomen. ${ }^{4}$ Gall stones and alcoholism together account for $80 \%$ of acute pancreatitis. ${ }^{5}$ Although the overall mortality rate for acute pancreatitis is $2-10 \%$, this is related primarily to the $10-30 \%$ of patients with severe disease characterized by pancreatic and peripancreatic necrosis. ${ }^{6}$ Chronic pancreatitis $(\mathrm{CP})$ is a chronic exocrine part inflammation which is accompanied by organ 
parenchyma destruction and fibrosis. ${ }^{7}$ The illness is ever progressing while often causing severe complications. ${ }^{8}$ The given disease is likely to have combinations such as pancreas cancer and high morbidity level. ${ }^{9}$ Chronic pancreatitis is one of the complications of acute pancreatitis.

Diagnosis remain clinical and can be supported by $1.5-2$ fold increase above the upper limit of normal of serum amylase and lipase. ${ }^{10}$ Currently CECT is the imaging modality of choice where areas of hypo perfusion correlate with necrosis. ${ }^{11}$ The treatment of AP is largely supportive. Use of antibiotics and drugs, which reduce the pancreatic secretion, have been studied extensively. ${ }^{12}$ Usually the goal of CP medical therapy is the reduction of disease clinical symptoms, pancreas exocrine and endocrine function substitution.

Inspite of technical advances in medical and surgical fields, acute pancreatitis remains a major cause of morbidity and mortality. ${ }^{12,13}$

\section{METHODS}

Total 142 patients with biochemical or radiological diagnosis of pancreatitis were enrolled over a period of 3 years for the study of which 100 patients were of acute pancreatitis, 32 patients were of acute on chronic pancreatitis and 10 patients were of chronic pancreatitis. Cases were studied with reference to clinical history and physical findings. During the first 48 hours, patients were stratified according to the Ranson's criteria. ${ }^{118}$ Patients were classified as having mild (score 0-2), moderate (score 3-4), severe (score 5-6) and critical/very severe pancreatitis (score 7 or more). Treatment was planned according to the severity of pancreatitis and presence or absence of complications with either conservative or surgical methods. Initial conservative management consists of nasogastric suction, intravenous administration of fluid, antibiotic and supportive care in all patients. An indwelling urinary catheter was placed in most patients to allow close monitoring of urine output. Most of the systemic complication was managed by conservative and supportive care including Intensive critical unit care. Patients were followed up for a period of 6 months to look for recurrence or complications developing after discharge. Data like clinical symptoms and signs, results of investigations, complications, surgical procedures if any, duration of hospital stay recurrence if any were carefully collected and compiled.

\section{RESULTS}

This was a prospective observational descriptive study consisting of 142 cases of Pancreatitis $(n=142)$. Of these, there were 100 patients of acute pancreatitis, 32 patients of acute on chronic pancreatitis and 10 patients of chronic pancreatitis.
Table 1: (a) Distribution of sex in our study.

\begin{tabular}{|ll|}
\hline Age groups & Present study \\
\hline 20 years & $9(6.34 \%)$ \\
\hline 20 to 40 years & $74(52.11 \%)$ \\
\hline 40 to 60 years & $47(33.10 \%)$ \\
\hline$>60$ years & $12(8.45 \%)$ \\
\hline
\end{tabular}

Table 1: (b) Distribution of sex in our study.

\begin{tabular}{|llll|}
\hline & $\begin{array}{l}\text { Present } \\
\text { Study }\end{array}$ & $\begin{array}{l}\text { Kashid A } \\
\text { et al }^{16}\end{array}$ & $\begin{array}{l}\text { Nagesh V R } \\
\text { et al }^{15}\end{array}$ \\
\hline Mean Age & 38.94 years & 35 years & 38.1 years \\
\hline
\end{tabular}

Table 2: Age distribution in our study.

\begin{tabular}{|ll|}
\hline Occupation & Total (percentage) \\
\hline Labourers (unskilled) & $100(70.42 \%)$ \\
\hline Student & $17(11.97 \%)$ \\
\hline Driver & $8(5.63 \%)$ \\
\hline Business (professionals) & $8(5.63 \%)$ \\
\hline Office workers & $7(4.93 \%)$ \\
\hline housewife & $2(1.41 \%)$ \\
\hline Total (percentage) & $\mathbf{1 4 2}(\mathbf{1 0 0 \%})$ \\
\hline
\end{tabular}

Table 3: Occupational distribution in our study.

\begin{tabular}{|ll|}
\hline Occupation & Total (percentage) \\
\hline Labourers (unskilled) & $100(70.42 \%)$ \\
\hline Student & $17(11.97 \%)$ \\
\hline Driver & $8(5.63 \%)$ \\
\hline Business (professionals) & $8(5.63 \%)$ \\
\hline Office workers & $7(4.93 \%)$ \\
\hline housewife & $2(1.41 \%)$ \\
\hline Total (percentage) & $\mathbf{1 4 2}(\mathbf{1 0 0 \%})$ \\
\hline
\end{tabular}

Males accounted for $92.25 \%$ of total patients and females accounted for $7.75 \%$ of the total patients with a male to female ratio of 11.9:1. Higher preponderance of males in our study is attributed to excessive alcohol consumption in our area. Consumption of alcohol in females is very low compared to western countries.

Table 4: Etiologic factors of pancreatitis in our study.

\begin{tabular}{|lll|l|}
\hline $\begin{array}{l}\text { Etiologic } \\
\text { factors }\end{array}$ & $\begin{array}{l}\text { Present } \\
\text { study }(\%)\end{array}$ & $\begin{array}{l}\text { Nagesh } \\
\mathbf{V ~ R}^{\mathbf{1 5}}\end{array}$ & $\begin{array}{l}\text { Kumar } \\
\text { A et al }\end{array}$ \\
\hline Alcohol & $78.17 \%$ & Rs 81.1 & 80 \\
\hline Gall Stones & $4.93 \%$ & 3.77 & 16 \\
\hline Miscellaneous & $16.9 \%$ & 15.1 & 4 \\
\hline
\end{tabular}

The highest incidence was noted in 20-40 years age group patients accounting for $52.11 \%$ of patients. The mean age of presentation was 38.94 years. This is probably because alcohol was the main etiological factor 
in our study which presents usually in the younger age group.

Labourers (unskilled workers) accounted for $70.42 \%$ of total patients. This is in correlation with alcohol consumption of these professions and since alcohol is the most common etiologic cause in this study accounting for $78.17 \%$ of cases, our study is comparable with other studies.

$78.17 \%$ of the total patients had alcoholic pancreatitis, $4.93 \%$ patients had gallstone pancreatitis, $16.9 \%$ patients had other miscellaneous causes like trauma, haemoglobinopathies, drugs, choledochal cyst, etc. People belonging to a rural setup where people are undereducated and there are lack of facilities for leisure and hence are prone to addictions leading to excessive alcohol consumption.

Abdominal pain was seen in all patients followed by vomiting and abdominal distention.

All patients had epigastric tenderness followed by abdominal distention.

Total 132 patients with acute episodes of pancreatitis were evaluated for severity of pancreatitis. 10 patients with chronic pancreatitis were excluded from the study as Ranson's prognostication criteria is not applicable to chronic pancreatitis patients.
Table 5: Presenting symptoms of patients in our study.

\begin{tabular}{|lllll|}
\hline $\begin{array}{l}\text { Presenting } \\
\text { complaints }\end{array}$ & $\begin{array}{l}\text { Present } \\
\text { study }\end{array}$ & $\begin{array}{l}\text { Kashid } \\
\text { et al }^{16}\end{array}$ & $\begin{array}{l}\text { Kumar } \\
\text { A et al }^{14}\end{array}$ & $\begin{array}{c}\text { Nagesh } \\
\text { VR et al }^{15}\end{array}$ \\
\hline $\begin{array}{l}\text { Abdominal } \\
\text { pain (\%) }\end{array}$ & 100 & 92.73 & 100 & 100 \\
\hline Vomiting (\%) & 85.21 & 60 & 82 & 83 \\
\hline Fever (\%) & 6.34 & 20 & 18 & 16.98 \\
\hline $\begin{array}{l}\text { Lump in } \\
\text { abdomen (\%) }\end{array}$ & 9.86 & 3.15 & - & 5.42 \\
\hline $\begin{array}{l}\text { Abdominal } \\
\text { distension (\%) }\end{array}$ & 37.32 & 16.36 & 42 & 33.96 \\
\hline Jaundice (\%) & 17.61 & 7.27 & 8 & 5.66 \\
\hline
\end{tabular}

Table 6: Abdominal findings in our study.

\begin{tabular}{|lll|}
\hline Abdominal Signs & $\begin{array}{l}\text { Present } \\
\text { study (\%) }\end{array}$ & $\begin{array}{l}\text { Nagesh V R } \\
\text { et al (\%) }\end{array}$ \\
\hline $\begin{array}{l}\text { Tenderness over the } \\
\text { Abdomen } \\
\text { (epigastric region) }\end{array}$ & 100 & 100 \\
\hline Abdominal distention & 45.77 & 33.96 \\
\hline Free fluid in the abdomen & 38.03 & 15.1 \\
\hline Lump in abdomen & 9.15 & 3.77 \\
\hline Hepatomegaly & 7.75 & - \\
\hline
\end{tabular}

Table 7: Severity of pancreatitis based on Ranson's score in our study.

\begin{tabular}{|lllll|} 
& Nagesh VR et al $(\%)^{\mathbf{1 5}}$ & Chen Y et al $(\%)^{17}$ & Present study (\%) & Mortality (percentage) \\
\hline Mild pancreatitis & 77.4 & 34.68 & $42(31.82)$ & $0(0 \%)$ \\
\hline Moderate pancreatitis & - & 42.28 & $65(49.24)$ & $0(0 \%)$ \\
\hline Severe pancreatitis & 22.6 & 10.63 & $23(17.42)$ & $1(4.34 \%)$ \\
\hline $\begin{array}{l}\text { Critical/very severe } \\
\text { pancreatitis }\end{array}$ & - & 12.40 & $2(1.52)$ & $1(50 \%)$ \\
\hline
\end{tabular}

Table 8: Line of management- conservative and surgical in our study.

\begin{tabular}{|llll|}
\hline & Nagesh VR et al $(\boldsymbol{\%})^{15}$ & ${\text { Raheman SA et al }(\boldsymbol{\%})^{\mathbf{1 8}}}$ & Present study $(\%)$ \\
\hline Conservative & 1.89 & 10.5 & $114(80.28 \%)$ \\
\hline Surgical & 98.11 & 89.5 & $28(19.72 \%)$ \\
\hline Total & & & $\mathbf{1 4 2}(\mathbf{1 0 0 \% )}$ \\
\hline
\end{tabular}

Table 9: Surgery performed in our study.

\begin{tabular}{|lll|}
\hline Type of Surgery & No. of patients $(\%)$ & \begin{tabular}{l} 
Indication for surgery \\
\hline Lateral pancreaticojejunostomy
\end{tabular} \\
\hline Cystogastrostomy & $10(35.71 \%)$ & $\begin{array}{l}\text { Ductal blockage due to calculus/stricture causing } \\
\text { recurrent attacks }\end{array}$ \\
\hline Whipple's (triple bypass) & $3(32.14 \%)$ & Pseudocyst of pancreas \\
\hline Hepaticojejunostomy & $2(7.14 \%)$ & Pancreatic/periampullary carcinoma \\
\hline ERCP & $1(3.57 \%)$ & Choledochal cyst \\
\hline Cholecystectomy & $1(3.57 \%)$ & Gallstone pancreatitis with CBD calculus \\
\hline
\end{tabular}




\begin{tabular}{|lll|}
\hline Necrosectomy & $1(3.57 \%)$ & Pancreatic necrosis \\
\hline External drainage of pseudocyst & $1(3.57 \%)$ & Infected pseudocyst of pancreas \\
\hline Total & $\mathbf{2 8 ( 1 0 0 \% )}$ & \\
\hline
\end{tabular}

Table 10: Duration of stay in hospital in our study.

\begin{tabular}{|lllll|}
\hline & $\begin{array}{l}\text { Duration of stay in } \\
\text { hospital (days) }\end{array}$ & $\begin{array}{l}\text { Average duration of stay in } \\
\text { hospital (days) }\end{array}$ & $\begin{array}{l}\text { Rehaman SA et } \\
\text { al (days) }\end{array}$ & $\begin{array}{l}\text { Nagesh VR et al } \\
\text { (days) }^{\mathbf{1 5}}\end{array}$ \\
\hline Mild pancreatitis & $3-6$ & 3.92 & 6.2 & 5.2 \\
\hline Moderae pancreaitis & $4-9$ & 4.54 & - & - \\
\hline Severe pancreatitis & $7-14$ & 7.64 & 6.7 & 6.7 \\
\hline Patients operated & $5-28$ & 9.83 & & \\
\hline
\end{tabular}

Table 11: Systemic complications of pancreatitis in our study.

\begin{tabular}{|c|c|c|c|}
\hline Complication & $\begin{array}{l}\text { Kashid A } \\
\text { et al }(\%)^{16}\end{array}$ & $\begin{array}{l}\text { Nagesh VR } \\
\text { et al }(\%)^{15}\end{array}$ & $\begin{array}{l}\text { Present } \\
\text { study }(\%)\end{array}$ \\
\hline Local necrosis & 18.18 & 3.77 & 11.27 \\
\hline Abscess & 5.45 & 0 & 1.41 \\
\hline Pseudocyst & 0 & 3.77 & 19.72 \\
\hline $\begin{array}{l}\text { Abdominal fluid } \\
\text { collections }\end{array}$ & 34.54 & 15.1 & 42.25 \\
\hline Pleural effusion & 34.54 & 16.98 & 7.75 \\
\hline Organ failure & 29 & 9.43 & 23.24 \\
\hline GI bleed & 1.8 & 1.89 & 0 \\
\hline $\begin{array}{l}\text { Metabolic } \\
\text { disturbances }\end{array}$ & - & - & 4.93 \\
\hline $\begin{array}{l}\text { Chronic } \\
\text { pancreatitis }\end{array}$ & - & - & 35.21 \\
\hline $\begin{array}{l}\text { Pancreatic duct } \\
\text { calculus }\end{array}$ & - & - & 5.63 \\
\hline
\end{tabular}

Table 12: Follow up: asymptomatic, symptomatic in our study.

\begin{tabular}{|llll|}
\hline & $\begin{array}{l}\text { Nagesh VR } \\
\text { et al }(\%)^{15}\end{array}$ & $\begin{array}{l}\text { Kumar A } \\
\text { et al }(\%)^{14}\end{array}$ & $\begin{array}{l}\text { Present } \\
\text { study }(\%)\end{array}$ \\
\hline $\begin{array}{l}\text { No complaints/ } \\
\text { asymptomatic }\end{array}$ & 92.45 & 54 & 67.63 \\
\hline $\begin{array}{l}\text { Readmissions/r } \\
\text { ecurrence }\end{array}$ & 7.55 & 16 & 20.14 \\
\hline
\end{tabular}

\section{DISCUSSION}

This was a prospective observational descriptive study consisting of 142 cases of pancreatitis $(n=142)$. Of these, there were 100 patients of acute pancreatitis, 32 patients of acute on chronic pancreatitis and 10 patients of chronic pancreatitis.

Males accounted for $92.25 \%$ of total patients and females accounted for $7.75 \%$ of the total patients with a male to female ratio of 11.9:1. Higher preponderance of males in our study is attributed to excessive alcohol consumption in our area. Consumption of alcohol in females is very low compared to western countries.

The highest incidence was noted in 20-40 years age group patients accounting for $52.11 \%$ of patients. The mean age of presentation was 38.94 years. This is probably because alcohol was the main etiological factor in our study which presents usually in the younger age group.

Labourers (unskilled workers) accounted for $70.42 \%$ of total patients. This is in correlation with alcohol consumption of these professions and since alcohol is the most common etiologic cause in this study accounting for $78.17 \%$ of cases, our study is comparable with other studies.

$78.17 \%$ of the total patients had alcoholic pancreatitis, $4.93 \%$ patients had gallstone pancreatitis, $16.9 \%$ patients had other miscellaneous causes like trauma, haemoglobinopathies, drugs, choledochal cyst, etc. People belonging to a rural setup where people are undereducated and there are lack of facilities for leisure and hence are prone to addictions leading to excessive alcohol consumption.

Abdominal pain was seen in all patients followed by vomiting and abdominal distention. All patients had epigastric tenderness followed by abdominal distension.

Total 132 patients with acute episodes of pancreatitis were evaluated for severity of pancreatitis. 10 patients with chronic pancreatitis were excluded from the study as Ranson's prognostication criteria is not applicable to chronic pancreatitis patients.

In our study, $31.82 \%$ of the total patients had mild pancreatitis with Ranson's score of $<2$ and mortality of $0 \%, 49.24 \%$ of the total patients had moderate.

Pancreatitis with Ranson's score of 2-3 and mortality of $0 \%, 17.42 \%$ of the total patients had severe pancreatitis with Ranson's score of 5-6 and mortality of $4.34 \%$, 
$1.52 \%$ of the total patients had very severe pancreatitis with Ranson's score of $>7$ and mortality of $50 \%$.

In our study, 114 patients $(80.28 \%)$ of total patients were managed conservatively whereas 28 patients $(19.72 \%)$ of total patients required surgical management in present or subsequent admissions.

In patients that underwent surgery, Lateral pancreaticojejunostomy was the most common procedure performed followed by cystogastrostomy.

In our study, duration of hospital stay for patients with mild pancreatitis was 3 to 6 days (average 3.92 days), duration of hospital stay for patients with moderate pancreatitis was 4 to 9 days (average 4.54 days) and patients with severe pancreatitis had 7 to 14 days of hospital stay (average 7.64 days). Duration of hospital stay for the patients who underwent surgical management was 5 to 28 day (average 9.83 days).

Among systemic complications, free fluid in abdomen was noticed in 60 patients (42.25\% of total patients), organ failure was noticed in 33 patients $(23.24 \%$ of total patients), pleural effusion was noticed in 11 patients (7.75\% of total patients), and metabolic disturbances was noticed in 7 patients $(4.93 \%$ of total patients). Complications like gastrointestinal bleeding and diabetes mellitus were not noted in our study. Higher percentage of chronic pancreatitis in our study is due to excessive alcohol abuse in our area leading to recurrent attacks and development of chronic pancreatitis.

In our study, 3 patients out of 142 died and hence no follow up was available. Of the remaining 139 patients who were under follow up, $67.63 \%$ of total patients were asymptomatic over 6 months follow up, $32.37 \%$ of total patients had recurrent pain at 6 months after discharge, whereas, $20.14 \%$ of total patients had to be readmitted with pancreatitis in 6 months after discharge.

Total 3 patients died during the study ( 2 of acute pancreatitis and 1 of chronic pancreatitis). 2 patients of acute pancreatitis succumbed to the complications of severe pancreatitis, whereas, 1 patient of chronic pancreatitis could not withstand the operative stress and succumbed in the post-operative period.

Present study demonstrates no mortality in mild and moderate pancreatitis, $4.34 \%$ mortality in severe pancreatitis and $50 \%$ mortality in patients with very severe/ critical pancreatitis. Overall mortality due to pancreatitis in our study is $2.11 \%$.

\section{CONCLUSION}

Acute pancreatitis is a common cause of acute abdomen in patients presenting to the surgical emergency department. Alcohol being the most common cause of acute pancreatitis in this part of the country, It has a male preponderance and most commonly presents in the $3 \mathrm{rd}$ or 4th decade of life. It is more common in unskilled workers like labourers. It is mainly a clinical diagnosis supplanted with biochemical and radiological findings. Pain in abdomen is the most common presenting symptom and tenderness over abdomen the most common sign on examination. Serum amylase, serum lipase, ultrasonography of abdomen and CECT abdomen being the most commonly used investigations for diagnosis. Several methods for prognostic stratification for severity of disease are being used. The management is mainly conservative with surgery limited to only a few selected cases, depending upon the severity of the disease. Severe pancreatitis is associated with increased mortality.

\section{Funding: No funding sources \\ Conflict of interest: None declared}

Ethical approval: The study was approved by the institutional ethics committee

\section{REFERENCES}

1. Fitz R. Acute Pancreatitis: a consideration of pancreatic hemorrhage, hemorrhagic, supurative and gangrenous pancreatitis, and of disseminated fat necrosis. Boston: 1889.

2. Opie E. The etiology of acute hemorrhagic pancreatitis. Bull John Hopkins Hospital. 1902;(74):398-401.

3. Thomson SR, Hendry WS, McFarlane GA, Davidson AI. Epidemiology and outcome of acute pancreatitis. Br J Surg. 1987;74(5):398-401.

4. Williams N, Bulstrode C, O'Connel P. The Pancreas. Chapter 64, Bailey and Love's Short Practice of Surgery. 25 ed. London 2008.

5. Shah SC, Shah PS. Aetiology and Pathogenesis of Acute Pancratitis Chapter 2. Bhansali S, Shah S, eds. Jaslok Hospital, 2006.

6. Clancy T, Ashley S. Management of acute pancreatitis Chapter 36, Maingot's Abdominal Operations. 11 ed. Zinner M, Ashley S, eds: McGraw-Hill; 2007.

7. Danilans A, Gardovskis J, Pokrotnicks J. Hronisks Pankreafits. Diagnozes un arstesanas standarts. Riga: Gastroenetrologijas Atbalsta fonds. 2002.

8. Lévy P, Barthet M, Mollard BR, Amouretti M, Marion-Audibert AM, Dyard F. Estimation of the prevalence and incidence of chronic pancreatitis and its complications. Gastroenterol Clin Biol. 2006;30(6-7):838-44.

9. Levy P, Milan C, Pignon JP, Baetz A, Bernades P. Mortality factors associated with chronic pancreatitis. Unidimensional and multidimensional analysis of a medical-surgical series of 240 patients. Gastroenterology. 1989;96(4):1165-72.

10. Steinberg WM, Goldstein SS, Davis ND, Shamma'a J, Anderson K. Diagnostic assays in acute pancreatitis. A study of sensitivity and specificity. Ann Intern Med. 1985;102(5):576-80. 
11. Balthazar EJ. CT diagnosis and staging of acute pancreatitis. Radiol Clin North Am. 1989;27(1):1937.

12. Steinberg W, Tenner S. Acute pancreatitis. N Engl J Med. 1994;330(17):1198-210.

13. Baron TH, Morgan DE. Acute necrotizing pancreatitis. N Engl J Med. 1999;340(18):1412-7.

14. Kumar A, et al. Clinical study, management of Complications of Acute Pancreatitis. Bangalore Medical College and Research Institute, Bangalore: Rajiv Gandhi University of Health Sciences, Karnataka 2010.

15. Nagesh VR. Clinical Study of Acute Pancreatitis and its Management. Karnataka Institute of Medical Sciences, Hubli: Rajiv Gandhi University of Health Sciences, Karnataka; 2011.
16. Kashid A. Acute Pancreatitis Experience at Manipal Hospital, Banglore, Appendix 1-A, Management of Acute Pancreatitis. Bhansali SK, Shah SC, eds. Jaslok Hospital, 2006.

17. Chen CC, Wang SS, Lee FY, Tsay SH, Wu SL, Lu $\mathrm{RH}$, et al. Prophylactic octreotide reduces the severity of histopathologic changes and hemodynamic shock in early taurodeoxycholateinduced experimental pancreatitis. Proc Natl Sci Counc Repub China B. 1999;23(1):1-6.

18. Rehaman SA, Chandrashekhar S, Reuben PJ. Clinical study of Acute Pancreatitis. Journal of Evolution of Medical and Dental Sciences. 2015;4(58):10142-55.

Cite this article as: Nandu VV, Deshpande AV. Clinical study of pancreatitis and its management. Int Surg J 2016;3:1574-9. 